Journal of Teaching and Learning with Technology, Vol. 4, No. 1, June 2015, pp. 40-60.

doi: $10.14434 /$ jotlt.v4n1.13002

\title{
Revisiting Use of Real-Time Polling for Learning Transfer
}

\author{
Sheri Stover', Dan Noel $^{2}$, Mindy McNutt ${ }^{3}$, \& Sharon G. Heilmann ${ }^{4}$
}

Abstract: Instructors in five different undergraduate courses designed their courses to include real-time polling to increase their students' levels of engagement and participation in an attempt to enhance students' learning transfer. Bjork (1994) defined learning transfer as "the ability to use information after significant periods of disuse and the ability to use information to solve problems that arise in a context different (if only slightly) from the context in which the information was originally learned" (p. 187). This mixed methods research study examined the results of those efforts after surveying students' perceptions of whether the use of real-time polling had an effect on their understanding of the course content and their levels of participation and engagement in the classroom. Instructors used Poll Everywhere to incorporate real-time polling in classes where $98 \%$ of students had suitable devices to respond to the polls. Results from this survey indicate that the use of real-time polling helped students better understand the course material and also increased their level of participation and engagement.

Keywords: real-time polling, Poll Everywhere, learning transfer

Faculty members in higher education have begun to implement clickers in their classroom. Clickers are also known as audience response systems and real-time polling. Clickers are hand-held devices that students use to respond to questions displayed on a computer projector. A receiver device records students' responses and then displays the aggregated results for the entire class to see (Campt \& Freeman, 2010). Most frequently, clickers are used to respond to multiple-choice questions, but some clickers allow students to type in short, openended responses. Clickers are sold for about $\$ 30$ to $\$ 40$ from manufacturers such as TurningPoint and iClicker (Kelly, 2011). These costs can place an additional financial burden on students, many of whom have reported dissatisfaction in being required to purchase a clicker and then having to remember to bring it to class (Patry, 2009).

Companies like Poll Everywhere now provide real-time polling where students can use their cell phones to respond to polls. The advantage of using cell phones is that students can use a tool that most of them have readily available (Dahlstrom, 2012). Poll Everywhere has an educational plan where instructors can utilize the polling for free in classes that have no more than 40 students. Once the polls are created, the instructor displays the questions on the computer projector for all students to see. Students can use their smart phones, feature phones, laptop computers, or tablets to respond to the real-time polls (Poll Everywhere, n.d.).

\footnotetext{
1 Department of Leadership Studies in Education and Organizations, Wright State University, 3640 Colonel Glenn Hwy., Dayton, OH 45435 sheri.stover@wright.edu

2 Department of Leadership Studies in Education and Organizations, Wright State University, 3640 Colonel Glenn Hwy., Dayton, OH 45435 dan.noel@wright.edu

${ }^{3}$ Department of Leadership Studies in Education and Organizations, Wright State University, 3640 Colonel Glenn Hwy., Dayton, OH 45435 mindy.mcnutt@wright.edu

4 Department of Leadership Studies in Education and Organizations, Wright State University, 3640 Colonel Glenn Hwy., Dayton, OH 45435 sharon.heilmann@wright.edu
} 
Stover, S., Noel, D., McNutt, M., \& Heilmann, S. G.

It is not the technology that enhances students' learning; however, it is the ways in which the instructor utilizes the technology. Real-time polling is important because it is a tool that can be utilized by instructors to implement teaching methodologies into their classroom that will enhance their students' learning transfer.

\section{Literature Review}

Many college faculty members continue to teach the way they were taught, using didactic lecture with a mid-term and a final exam to assess students' learning (Halpern \& Hakel, 2003). This results in students who can achieve satisfactory grades by memorizing the material to pass the test, but does not result in a large numbers of students being able to transfer their learning to future situations (Bransford, Brown, \& Cocking, 2000). Instructors need to incorporate teaching methodologies that help prepare students to be independent learners, capable of applying their learning in authentic situations beyond their college classes (Halpern \& Hakel, 2003). This literature review will outline the current research on learning transfer and address whether the use of real-time polling can enhance the design of a class to improve learning transfer.

Ratey (2002) defined learning as a change in the neural networks in the brain. He concluded that the brain has the ability to store information in its short-term recall; thus, students can memorize information and retrieve it for tests. However, if the information is not used again, it is purged from the brain (Ratey, 2002). Bjork (1994) defined learning transfer as "the ability to use information after significant periods of disuse and the ability to use information to solve problems that arise in a context different (if only slightly) from the context in which the information was originally learned" (p. 187). The primary mandate/undertaking of colleges and universities is to teach in order for students to be able to transfer their learning. In other words, transferring knowledge implies that students can accurately recall and use knowledge, skills, and attitudes learned in college at a later time in their career (Schwartz \& Bransford, 1998). Since it is challenging to predict the types of situations in which students will be required to apply their knowledge, the aim of higher education should be to facilitate students' ability to transfer what they have learned so students can independently implement solutions (Halpern \& Hakel, 2003).

Most instructors assume that learning transfer happens once students have successfully completed the class, but this does not always happen (Leimbach \& Maringka, 2009). Wiggins (2012) found that students have challenges transferring the content learned in previous classes unless the classes are specifically designed for learning transfer. Classes that are designed to enhance students' learning transfer need to ensure that students have high levels of engagement and participation. Student engagement is defined as the "time, energy, and resources [that students] spend on activities designed to enhance learning" (Exeter, et al., 2010, p. 762). Student participation is defined as a "student's willingness, need, desire, and compulsion to participate in, and be successful in, the learning process" (Bomia et al., 1997, p. 3). Classes that are designed to enhance learning transfer and include high levels of student engagement and participation include the following characteristics.

\section{Active Participation.}

The first characteristic of classes designed to enhance learning transfer is that students are active participants in the learning process. Students cannot simply be passive learners who are merely exposed to information through didactic lecture and assessed at surface levels (Bransford

Journal of Teaching and Learning with Technology, Vol. 4, No. 1, June 2015. jotlt.indiana.edu 
et al., 2000). It is critical that students gain deep understanding, which requires them to spend a substantial amount of time working with the academic content. When students are repeatedly required to generate responses to real-time polling questions with minimal cues, they strengthen their neural connections. Halpern and Hakel (2003) refer to this strategy as "the single most important variable in promoting long-term retention and transfer" (p. 38). Requiring students to frequently retrieve information creates a "memory trace" and repeated practice strengthens the neural connections. Incorporating frequent real-time polling during each class moves students from being passive learners to becoming active participants by continually requiring them to "practice at retrieval" (Halpern \& Hakel, 2003, p. 38).

Classes in which students are passive learners and receive information from teachers who lecture result in student memorization and 'cramming' in preparation for tests (Organization of Economic Cooperation and Development, 2009). Students may receive good grades because the brain's short-term recall can store information for 18 to 36 hours (Bjork, 1994). If students do not continue to practice using that information, any new cellular material is reabsorbed by the brain and the information is not retained (Zadina, 2008). In a lecture-based classroom, the instructor is the one who is firing his or her own neuron network and the students are in a state of passivity (Doyle, 2011). In a teacher-centered approach, instructors feel pressured to "cover" their course material and they march through the textbook material to ensure that every chapter of the book is covered. This learning is inert and does not result in high levels of transfer (Bransford, Franks, Vye, \& Sherwood, 1989). Wiggins and McTighe (2005) called this approach to teaching, "Teach, test, and hope for the best" (p. 3). In this approach, the implicit assumption is that learning transfer simply takes care of itself. Rogers (1983) argued the need to change teacher-centered learning environments because "students become passive, apathetic, and bored" (p. 25). The incorporation of real-time polling can enhance students' levels of engagement and participation (Patry, 2009) because it can help shift learning environments from teacher-centered to learner-centered by requiring students to participate by using their polling device to respond to polling questions (McCabe, 2006).

\section{Deep Understanding.}

The second characteristic of classes that enhance learning transfer is that students need to move from simple memorization to deep understanding with abstract and contextual knowledge. Students become engaged when given opportunities to experience abstraction, which is the process of allowing students to apply the content to other contexts (Bransford et al., 2000). Students also need to move beyond the lower-level thinking skills such as remembering and understanding and move to the higher-order thinking skills of applying, analyzing, evaluating, and creating (Krathwohl, 2002; Renkl, Atkinson, Maier, \& Stanley, 2002).

Mazur (1977), a Physics and Applied Physics professor at Harvard University, began using real-time polling to ensure his students had deeper levels of understanding. Mazur continues to use real-time polling to deepen students' understanding by interspersing his lectures with conceptual questions that are designed to expose challenges in understanding the material. The questions he uses require students to use their higher-level application skills to be able to provide a response. Mazur gives students a few minutes to deliberate, and then must commit to an answer by using the polling device. Using this methodology allows instructors to quickly gauge students' understanding through the instructor response dashboard that summarizes the students' responses (Miller, Lasry, Lukoff, Schell, \& Mazur, 2014). When classes have high

Journal of Teaching and Learning with Technology, Vol. 4, No. 1, June 2015. jotlt.indiana.edu 
levels of misunderstanding, Mazur asks students to spend a few minutes in groups of three or four in order for them to reach consensus on the correct answer. Students then need to think through their arguments and discuss them with other students; this process allows them to deepen their level of understanding and also clarify any misunderstandings. Since students are trying to convince each other of the correct answer, this type of teaching methodology is called peer instruction (Mazur, 1997). Following student discussions, instructors have students use the polling device to vote again. Instructors can then share the correct answer and respond to any lingering questions or provide clarification, if needed. The use of real-time polling in peerinstruction is an excellent strategy to help enhance students' learning transfer because it requires students to be actively engaged. Students need to apply their knowledge and then defend their answers, instead of simply sitting passively in class and taking notes (Lambert, 2012).

\section{Frequent Assessments.}

The third characteristic of classes designed to maximize learning transfer is that students are actively involved with frequent assessments that are distributed throughout the class. Students should not be assessed with one-time tests such as a single mid-term or final exam, but be continually assessed using active, dynamic, and continual processes (Bransford et al., 2000). Incorporating polling into each and every class requires students to be continually assessed, which requires them to stay engaged and results in better long-term retention (Pashler, Rohrer, Cepeda, \& Carpenter, 2007). Polling can also allow students to review course content by assessing prior knowledge (Abrahamson, 1999). Once stored, it is important to continue to review the information on a regular basis, thereby strengthening connections between neurons (Willis, 2006).

Instructors teaching Educational Psychology at the University of California found their students scored significantly higher on exams when they used clickers during class as formative assessments to respond to frequent exam-like questions compared to students enrolled in classes not using clickers. The researchers felt the clickers increased student learning because: (a) students needed to pay closer attention to the course material to be able to correctly answer the exam-like questions; (b) students needed to organize and integrate their course material in their brains while formulating answers, and (c) students develop metacognitive skills for gauging their levels of understanding of the course material (Mayer et al., 2009).

Instructors teaching a large enrollment introductory psychology class embedded questions throughout the lecture as a formative assessment method to test students' level of understanding. The researchers found the students in classes using clickers had significantly higher scores $(p<.05)$ than students enrolled in sections not using this teaching methodology (Powell, Straub, Rodriguez, \& VanHorn, 2011).

\section{Increase use of Senses.}

The fourth characteristic of classes designed to encourage higher learning transfer is that students are required to use more of their senses (Seitz, Kim, \& Shams, 2006). Real-time polling can be used in class to help students utilize more of their senses while learning course content. For example, students use their visual memory when seeing the questions, problem sets, and possible answers displayed on PowerPoint slides. Students also use their auditory memory when hearing their instructor talk about the questions and later, if students are to discuss the answers

Journal of Teaching and Learning with Technology, Vol. 4, No. 1, June 2015. jotlt.indiana.edu 
with their peers. Additionally, students use their tactile-kinesthetic memory when moving their body from a potentially bored, inattentive, passive listener position to a more alert one in which they prepare to use the polling device to choose an answer. Furthermore, students also activate their feelings of excitement as they begin to generate eagerness when they are required to make a choice on the polling device. The more senses students use in practicing their learning, the more pathways become available for recall (Seitz et al., 2006). Implementing multisensory learning environments allows for more effective learning transfer for longer periods of time (Medina, 2008). "Learning will happen more effectively if the learner is as involved as possible, using as many of his [or her] faculties as possible, in the learning" (Crosby, 1981, p. 10).

\section{Visible Learning.}

The fifth characteristic of classes that are designed for strong learning transfer is that classes include activities that require students to make their learning visible, clarify any misconceptions, and develop their metacognition (Bransford et al., 2000). Metacognition is a person's awareness of their own thinking and their ability to plan, monitor, evaluate, and repair cognitive learning (Kirsh, 2005). Incorporating real-time polling with appropriately crafted questions is an excellent strategy to help students strengthen their metacognition because it requires students to repeatedly and frequently apply knowledge to answer questions and receive immediate feedback about their level of understanding of the topic (Manke-Brady, 2012). This is important because Halpern and Hakel (2003) found that students are poor judges of how well they understand complex topics and will develop misunderstandings if they do not have ways to accurately judge their levels of understanding. Chabris and Simons (2009) outlined why students' develop misunderstandings by explaining that people have challenges with their perception, memory, attention, and reasoning. They went on to note that people frequently miss a lot of things happening around them, but due to inattentional blindness, they have no idea what they are missing. Developing lessons that help students identify their misconceptions allows them to learn content at deeper levels for longer retention.

\section{Increased Participation and Engagement.}

The sixth characteristic in classes designed for effective learning transfer is that classes are designed to require students to have high levels of participation and engagement in order to keep students' attention. Penner (1984) found that student attention and concentration drops off dramatically after 10 to 15 minutes. Research studies have shown that the human brain is not equipped to pay attention to auditory information for long periods of time, regardless of the students' grade level or ability (Milton, Pollio, \& Eison, 1986). Bligh (2000) conducted research to show that when students spend prolonged periods of time on a repetitive task such as note taking, their lower centers of the brain (mindless behavior) becomes activated. Research in neuroscience has suggested that students need to practice and use information to allow them to see how the information has interconnections and how it can be used in other contexts to enhance learning transfer (deWinstanley \& Bork, 2002). If students are going to achieve learning beyond lower-level information acquisition, they need to be actively engaged in the process of learning (Pascarella \& Terenzini, 2005). "If we want students to become more effective in meaningful learning and thinking, they need to spend more time in active, meaningful learning and thinkingnot just sitting and passively receiving information" (McKeachie, Pintrich, Lin, \& Smith, 1986,

Journal of Teaching and Learning with Technology, Vol. 4, No. 1, June 2015. jotlt.indiana.edu 
Stover, S., Noel, D., McNutt, M., \& Heilmann, S. G.

p. 77). Incorporating real-time polling is a good way to break-up long lectures (Addison, Wright \& Milner, 2009) and will ensure that students have high levels of engagement and participation which will lead them to develop stronger neural connections to maximize learning transfer (Doyle, 2011).

\section{Research Questions}

The instructors involved in this research study attempted to utilize the real-time polling in their classes to maximize learning transfer of students by increasing students' levels of engagement and participation. The researchers attempted to answer the following questions:

1) Does the use of real-time polling have an impact on students' perceived levels of participation and engagement?

2) Does the use of real-time polling have an impact on students' perceived ability to understand the course material?

\section{Method}

Three instructors in five different classes used real-time polling in an attempt to increase students' levels of engagement and participation in order to enhance students' learning transfer.

\section{Demographics}

The students in this research study were enrolled in classes at a mid-sized university in the Midwest in the United States. The survey was given to 97 participants in five different classes taught by three different instructors. There were two students who did not have a device to utilize for the real-time polling and could not participate, so they only completed the demographics section of the survey. The students in the survey were majoring in Organizational Leadership, which is designed to prepare them to become managers and supervisors in the private, public, and nonprofit sectors. All students taking the survey were undergraduates with the majority being seniors $(\mathrm{N}=56)$, the next being juniors $(\mathrm{N}=39)$, and the least of them being sophomores $(\mathrm{N}=2)$. The age of the participants ranged from 18-24 $(\mathrm{N}=57), 25-30(\mathrm{~N}=21)$, 31-40 $(\mathrm{N}=9), 41-50(\mathrm{~N}=9)$, and 50 and over $(\mathrm{N}=1)$. The gender make-up of the participants was more male $(\mathrm{N}=53)$ than female $(\mathrm{N}=44)$. The racial mix of the participants was Caucasian $(\mathrm{N}=72)$, African American $(\mathrm{N}=21)$, Other $(\mathrm{N}=2)$, Asian $(\mathrm{N}=1)$, and Hispanic/Latino $(\mathrm{N}=1)$.

\section{Instrument}

Students were asked to complete a paper and pencil survey to measure their perceptions of using the Poll Everywhere real-time polling. The survey was administered by someone other than the classroom instructor, to assure students' privacy. The survey was administered during the last week of a semester class. Students completed a 49-question survey that was developed by the researchers. The survey included questions about students' demographics, the type of device they used, their level of participation and engagement, their thoughts about learning transfer, and their thoughts about using real-time polling in the future. Utilizing a Likert Scale, students responded to statements with a (1) Strongly Agree (SA), (2) Agree (A), (3) Disagree (D), or (4) Strongly Disagree (SD). Additionally, students were asked to provide comments

Journal of Teaching and Learning with Technology, Vol. 4, No. 1, June 2015. jotlt.indiana.edu 
Stover, S., Noel, D., McNutt, M., \& Heilmann, S. G.

about the impact of real-time polling on their level of understanding, satisfaction, participation, and engagement by responding to open-ended questions.

\section{Procedure}

Instructors in five different classes asked students to use Poll Everywhere as a real-time polling device to respond to polling questions while teaching their classes. Students used their personal devices (cell phones, lap top, or tablet) to respond to these real-time polls. Quantitative data were gathered from students by asking them to complete a survey questionnaire that asked students to give their perceptions about how the use of real-time polling had an impact on their level of understanding and their level of participation and engagement. Students were given statements such as "Using real-time polling during class helps me to better understand the class material" and then select if they (1) Strongly Agree, (2) Agree, (3) Disagree, or (4) Strongly Disagree. Students' Likert scale responses were entered into an Excel spreadsheet and then imported into SPSS 21 for quantitative data analysis. On the quantitative survey, there were six questions designed to measure for student participation and nine questions designed to measure for engagement. Exploratory factor analysis (EFA) with principal axis factoring and varimax rotation was used to identify the underlying relationships between the survey items (Norris \& Lecavalier, 2009). Results are displayed in Table \#1. Principal axis factoring assumes all variables have been measured with some degree of error (Kim \& Mueller, 1978). Varimax (orthogonal) rotation attempts to minimize the number of variables that have high factor loadings, thus interpretability of factors can be enhanced. Bartlett's test of sphericity $\left(\chi^{2}=651.93\right.$, $\mathrm{p}<.01)$ indicates the correlation matrix is an identity matrix; thus data appear to be a sample from a multivariate normal population.

\section{Table 1. Rotated Factor Matrix}

\begin{tabular}{|c|c|c|c|}
\hline & \multicolumn{3}{|c|}{ Factor } \\
\cline { 2 - 4 } & 1 & 2 & 3 \\
\hline Q23 & & -.545 & \\
Q24 & .461 & .736 & \\
Q25 & .583 & .465 & \\
Q26 & .684 & & \\
Q27 & .707 & & \\
Q28 & & & .380 \\
Q31 & .686 & & \\
Q32 & .764 & & \\
Q33 & .766 & & \\
Q34 & .709 & & \\
Q35 & & & -.442 \\
Q36 & .722 & & \\
Q37 & .783 & & \\
Q38 & .760 & & \\
Q39 & .571 & & .490 \\
\hline
\end{tabular}

Journal of Teaching and Learning with Technology, Vol. 4, No. 1, June 2015. jotlt.indiana.edu 
Stover, S., Noel, D., McNutt, M., \& Heilmann, S. G.

The most conservative approach to interpreting the rotated factor matrix was employed; thus any items that loaded across multiple factors were removed. The final variable, Classroom Engagement and Participation, is comprised of items 26, 27, 31, 32, 33, 34, 36, 37, and 38. The Cronbach's Alpha for Classroom Engagement and Participation is .92, which indicates an excellent level of internal consistency among these questions (George \& Mallery, 2011).

Qualitative data were gathered from opened-ended questions where students were asked two open-ended questions about their thoughts about how the use of real-time polling impacted their comfort level speaking in class and how it impacted their level of attention and engagement. The responses to opened-ended questions were imported into NVvio 10 research software for qualitative analysis to group with common themes.

\section{Results}

The results section summarizes the results from the student survey that measures students' perceptions about the incorporation of real-time polling in their class.

\section{Research Question \#1}

The first research question asked if the use of real-time polling had an impact on students' level of participation and engagement. In total, there were nine questions on the survey measuring the impact. Cronbach's Alpha, the measure for internal consistency, revealed internal consistency of .92 which indicates an excellent level of internal consistency (George \& Mallery, 2011). These nine questions were combined to develop a total score to summarize students' perceptions of how the use of real-time polling had an impact on their level of participation and engagement $(M=1.5 ; S D=.45$. $)$.

Four of these questions about students' level of participation and engagement asked students how the use of real-time polling impacted their classroom communication (see Table 2). The questions which the students agreed with from most to least included: (1) I feel that using real-time polling during class enhances the quality of discussions $(M=1.46)$; (2) I like that my polling responses are anonymous $(M=1.48)$; (3) The use of real-time polling in class enhances controversial discussions $(M=1.51)$, and (4) Using real-time polling in class makes me feel as if I have a voice to contribute during class discussions $(M=1.71)$.

Journal of Teaching and Learning with Technology, Vol. 4, No. 1, June 2015. jotlt.indiana.edu 
Stover, S., Noel, D., McNutt, M., \& Heilmann, S. G.

Table 2. Real-time polling survey: Participation \& Engagement questions

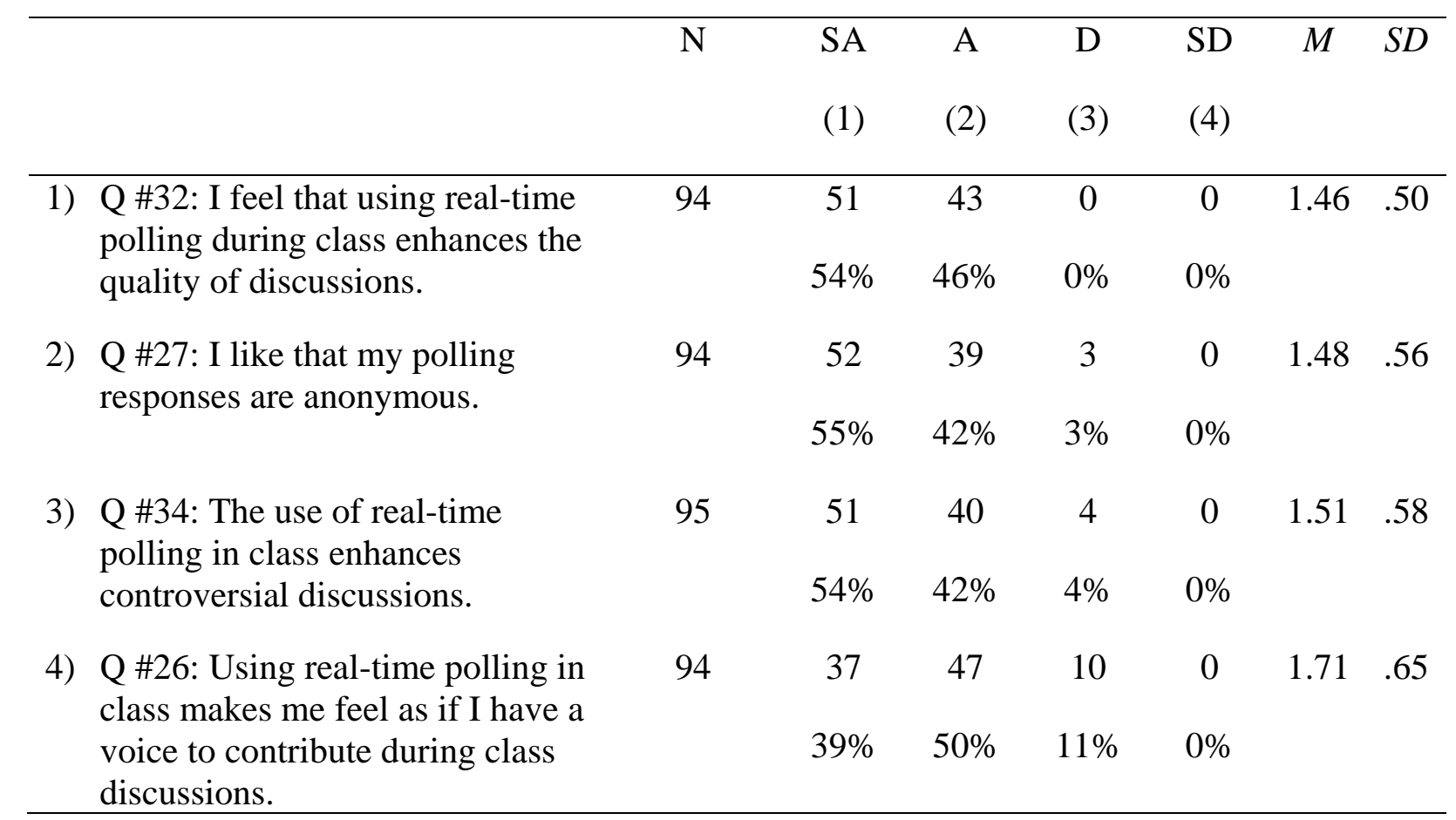

There were three questions that asked if students felt the use of real-time polling increased levels of participation and engagement because it impacted their enjoyment (see Table 3 ). The questions students agreed with from most to least included: (1) I like using a personal mobile device to engage in real-time polling during class $(M=1.36)$; (2) Using mobile devices for real-time polling during class is fun $(M=1.40)$; and (3) I wish that other instructors would use real-time polling in their classes $(M=1.49)$.

Table 3. Poll Everywhere Survey: Enjoyment and fun questions

\begin{tabular}{lccccccc}
\hline & $\mathrm{N}$ & $\mathrm{SA}$ & $\mathrm{A}$ & $\mathrm{D}$ & $\mathrm{SD}$ & $M$ & $S D$ \\
& & $(1)$ & $(2)$ & $(3)$ & $(4)$ & & \\
\hline 1) $\begin{array}{l}\mathrm{Q} \# 31 \text { : I like using a personal } \\
\text { mobile device to engage in real } \\
\text { time polling during class. }\end{array}$ & 95 & 63 & 30 & 2 & 0 & 1.36 & .52 \\
2) $\begin{array}{l}\mathrm{Q} \# 33 \text { : Using mobile devices for } \\
\text { real-time polling during class is } \\
\text { fun. }\end{array}$ & 95 & 60 & 32 & 3 & 0 & 1.40 & .55 \\
3) $\begin{array}{l}\text { Q \#38: I wish that other } \\
\text { instructors would use real-time } \\
\text { polling in their classes }\end{array}$ & 95 & 50 & 43 & 2 & 0 & 1.49 & .54 \\
\hline
\end{tabular}

Journal of Teaching and Learning with Technology, Vol. 4, No. 1, June 2015. jotlt.indiana.edu 
There were two questions on the survey (see Table 4) that measured students' thoughts on whether they believed real-time polling kept them engaged and attentive. The questions with which the students agreed with from most to least included: (1) I feel more connected to the class when participating with real-time polling $(M=1.65)$ and $(2)$ I become attentive when my instructor directs us to respond using real-time polling $(M=1.67)$.

Table 4. Poll Everywhere Survey: Engagement questions

\begin{tabular}{lccccccc}
\hline & $\mathrm{N}$ & $\mathrm{SA}$ & $\mathrm{A}$ & $\mathrm{D}$ & $\mathrm{SD}$ & $M$ & $S D$ \\
& & $(1)$ & $(2)$ & $(3)$ & $(4)$ & & \\
\hline $\begin{array}{l}\text { 1) } \mathrm{Q} \# 37 \text { : I feel more connected to } \\
\text { the class when participating with } \\
\text { real-time polling. }\end{array}$ & 94 & 43 & 42 & 8 & 1 & 1.65 & .68 \\
$\begin{array}{l}\text { 2) } \mathrm{Q} \# 36 \text { : I become attentive when } \\
\text { my instructor directs us to respond }\end{array}$ & 95 & 39 & 48 & 8 & 0 & 1.67 & .63 \\
& & $46 \%$ & $44 \%$ & $9 \%$ & $1 \%$ & & \\
using real-time polling. & & $41 \%$ & $51 \%$ & $8 \%$ & $0 \%$ & & \\
\hline
\end{tabular}

Open-ended comments were grouped into categories where students indicated the use of real-time polling had an impact on their participation and engagement. The two categories identified were an impact on their active participation and also their levels of participation and engagement. In the first category of active participation, some students felt the real-time polling allowed them to be more fully active in the class for those students that were shy and they felt the polling gave them a voice (see Table 5).

Table 5. Student comments about effect of real-time polling on giving them a voice

1) Sometimes I can feel uncomfortable speaking in class, this definitely provides an outlet for people to be heard, no matter what the comfort level AND takes less time than hearing everyone's opinion.

2) I get nervous speaking in front of people and with the polling I can still get my statement made without being shy.

Some students felt they could be more active in the classroom using real-time polling because it allowed them to respond anonymously and they could express their opinions without being judged (see Table 6).

Journal of Teaching and Learning with Technology, Vol. 4, No. 1, June 2015. jotlt.indiana.edu 
Stover, S., Noel, D., McNutt, M., \& Heilmann, S. G.

Table 6. Student comments about effect of real-time polling on being judged

1) I don't speak up b/c [sic] I am often the one who knows the answers and don't want to be the "teacher's pet".

2) [I don't speak up because I] feel uncomfortable when I think people are judging my disability.

3) I love that it is anonymous, I don't feel judged or anxious.

Some students did not believe that real-time polling had any effect on their active participation because they felt comfortable speaking up in class and commented, "I prefer getting credit for my ideas rather than anonymous responses."

The second category identified in the open comments was related to comments regarding how real-time polling impacted their levels of participation and engagement. The majority of comments from students indicated that the use of real-time polling had a positive impact on their level of engagement. Most students felt that the use of real-time polling helped them to stay focused and have fun with comments such as those listed in Table 7.

\section{Table 7. Effect of real-time polling on participation and engagement due to focus and fun}

1) Just makes you pay attention.

2) It keeps things moving and energetic! It's not just passing through lecture slides [and] offers something more.

3) It makes class fun.

4) Feel more engaged.

Students also felt the use of real-time polling impacted their levels of participation and engagement because it allowed everyone in the class to feel included (see Table 8).

Table 8. Effect of real-time polling on participation and engagement due to inclusion

1) They are a good way to interact with the class and keep everyone involved.

2) I think it allows everyone to feel like they can contribute to the class discussion.

3) I don't mind speaking up in class. I sometimes have exactly the same thing to say as someone else and that may be why I don't say much but I also enjoy using the Real time polling because it gives the whole class a voice.

\section{Research Question \#2}

The second research question asked if the use of real-time polling had a perceived impact on students' ability to understand the course material. There were $90 \%$ of the students who strongly agreed or agreed (see Table 9) that the use of real-time polling helped them to better understand the material $(M=1.84, S D=.57)$.

Journal of Teaching and Learning with Technology, Vol. 4, No. 1, June 2015. jotlt.indiana.edu 
Stover, S., Noel, D., McNutt, M., \& Heilmann, S. G.

Table 9. Poll Everywhere Survey: Perceived Student Learning

\begin{tabular}{lccccccc}
\hline & $\mathrm{N}$ & $\mathrm{SA}$ & $\mathrm{A}$ & $\mathrm{D}$ & $\mathrm{SD}$ & $M$ & $S D$ \\
& & $(1)$ & $(2)$ & $(3)$ & $(4)$ & & \\
\hline $\begin{array}{l}\text { Using real-time polling during class } \\
\text { helps me to better understand the } \\
\text { class material. }\end{array}$ & 94 & 24 & 61 & 9 & 0 & 1.84 & .57 \\
\hline
\end{tabular}

A bivariate analysis was conducted to determine the empirical relationship between Perceived Student Learning and Classroom Engagement and Participation. The bivariate correlation between the two variables of Perceived Student Learning and Classroom Engagement and Participation is significant $(r=.55, \mathrm{p}<.01, \mathrm{n}=91)$. There was evidence to conclude there is a significant association between Classroom Engagement and Participation and Perceived Student Learning.

To evaluate differences in perceptions between individuals with high perceptions of learning transfer (comprised of Strongly Agree and Agree) and low perceptions (comprised of Disagree and Strongly Disagree), an independent sample t-test was computed using Classroom Participation and Engagement as the test variable and Perceived Student Learning as the grouping variable (Group 1=Strongly Agree and Agree; Group 2=Disagree; Note; 0 responses for Strongly Disagree). Results indicated the difference $(M D=.52, t(9.60)-3.50, p<.001$, equal variances assumed) between students with higher perceptions of learning transfer reported greater perceptions of overall engagement than students with lower perceptions of learning transfer ( $m=1.48, n=82, \mathrm{~s} d=42 ; m=2.00, n=9, \mathrm{~s} d=.42$, respectively, where lower scores indicate higher levels of perceived overall engagement).

Open-ended comments were grouped into categories where students indicated the use of real-time polling had an impact on their learning. The three categories identified were visible learning, frequent assessments, and deeper learning. Students felt that the use of real-time polling allowed instructors to craft questions where students' responses help make learning visible. Students made comments in the first category with comments such as comments in Table 10.

\section{Table 10. Impact of real-time polling on students' learning by making learning visible}

1) Totally engages you and you know what your level of understanding is.

2) I really enjoy this. I think it keeps students involved while in class. It reminds me of how when you're in grade school and you write your answer on your white board.

3) It lets you see how almost the whole class views a particular subject.

4) I felt that polling allows me to see how others feel

Another category that was identified from open comments was that instructors could use real-time polling to quickly and frequently assess students (see Table 11).

Journal of Teaching and Learning with Technology, Vol. 4, No. 1, June 2015. jotlt.indiana.edu 
Stover, S., Noel, D., McNutt, M., \& Heilmann, S. G.

\section{Table 11. Impact of real-time polling on students' learning with frequent assessments}

1) Sometimes I can feel uncomfortable speaking in class, this definitely provides an outlet for people to be heard, no matter what the comfort level AND takes less time than hearing everyone's opinion.

2) I felt it was a faster way to get my point and answer across.

3) I thought it was great, makes me feel accountable.

The third category identified from open comments was that instructors could use realtime polling to encourage deeper learning. Students reported that when results of real-time polls were displayed, it sparked a good class discussion (see Table 12).

\section{Table 12. Impact of real-time polling on students' perceived learning with deeper learning}

1) I fell helps start good class discussion.

2) I like seeing the results pop up on the screen and the discussions afterword.

3) I think real time polling helps me to speak in class because it can [help me to] feel comfortable about what I say if I see that others would agree.

\section{Discussion}

Bransford et al. (2000) found that it is necessary for instructors to design classes where students have high levels of participation and engagement to enhance students' learning transfer. Design strategies to enhance learning transfer are classes where instructors require students to have active participation, deep levels of understanding, frequent assessments, increased use of their senses, make their learning visible, and high levels of participation and engagement. This section discusses if the incorporation of real-time polling had an impact on these characteristics designed to enhance learning transfer.

\section{Active Participation.}

Halpern and Hakel (2003) found that learning transfer is enhanced by requiring students to practice at retrieving content by actively participating instead of passively listening to lectures. Getting students to actively participate in class may be a challenge to many instructors and incorporating real-time polling can give instructors tools to enable this. Some students admitted that they were shy and that real-time polling helped give them a voice (89\%). Most students communicated appreciation of the anonymous nature of the polling (97\%). Some of the openended comments revealed that there were students who felt comfortable speaking in class and that for them, the real-time polling made no difference.

\section{Deeper Understanding.}

The incorporation of real-time polling followed by class discussion has been shown to deepen students' understanding of course concepts (Mazur, 1977). The students in this study overpoweringly indicated that the use of real-time polling helped them to better understand the

Journal of Teaching and Learning with Technology, Vol. 4, No. 1, June 2015. jotlt.indiana.edu 
class material with $90 \%$ agreeing with this statement. Students unanimously agreed that the use of real-time polling helped the quality of the discussion with $100 \%$ agreeing and $96 \%$ of them indicating that it enhanced controversial questions. Students felt the real-time polling encouraged deeper understanding because the results of the polls would be displayed and spark a good discussion. Some students felt more comfortable joining the discussion when they could see their opinions would be supported from the poll results.

\section{Frequent Assessments.}

Karpicke and Roediger (2006) found that when study preparation time is equal, students that used assessment tools in their study preparation significantly improved their long-term retention compared to students using review methods for studying. Incorporating assessments requires students to be actively involved in their learning since their brain is retrieving information and the effort deepens and strengthens their neural connections (Larsen, Butler, \& Roediger, 2013). Students in this study reported the incorporation of real-time polling allowed instructors to quickly and frequently assess students with polling questions. Instructors that incorporate real-time polling requires all the students to actively engage with assessment by responding to the polling questions, instead of a few that might verbally answer a question during class. The regular incorporation of real-time polling made some students believe they were accountable since they were being frequently polled.

\section{Increased use of senses.}

Many classroom instructors can intuitively read their students' body language to judge their level of alertness. The instructors noted that students' physical demeanor would change when polling questions were included by moving from a relaxed posture to an attentive and engaged demeanor. Students use more of their senses when asked to pick up their real-time polling device as they are seeing the question, touching their responding device, and feeling the excitement as they prepare to select their response. Seitz et al. (2006) found that the more senses that students use while learning the better as more pathways become available for recall. There were $92 \%$ of the students felt the use of real-time polling required them to become more attentive.

\section{Visible learning.}

Traditional studying methods such as reading the textbook and highlighting the course material can cause students to have a "fluency illusion" because they understand the material and believe they have mastered the content (Carey, 2014). The students in these classes reported that the use of real-time polling allowed the instructor to make learning visible when they displayed the aggregate results of each poll. This allowed students to see how the other participants in class felt about the questions or how they stacked up against their peers. One student compared the use of real-time polling to the process of going to a whiteboard to make their learning visible.

\section{Increased participation and engagement.}

The majority of university classes last from 50 to 90 minutes, which is much longer than

Journal of Teaching and Learning with Technology, Vol. 4, No. 1, June 2015. jotlt.indiana.edu 
the typical attention span of most college students. Bunce, Flens, and Neiles (2010) found that classes designed using real-time polling to enhance active learning results in fewer attention lapses due to the engaging of students' attention. The student in this research study indicated that the use of real-time polling helped them feel higher levels of engagement with most of the students indicating that they wished other instructors would implement it (98\%). Students felt that using real-time polling was fun (97\%), and made them more connected to the class (90\%). The open-ended comments supported this with almost all comments conveying that real-time polling helped to get their attention.

\section{Considerations for Implementing Real-Time Polling}

Instructors will not only face challenges in learning the technical steps of setting up realtime polling, but also face pedagogical challenges to ensure the implementation of real-time polling results in learning enhancements. Many universities will offer technical training workshops which will help instructors learn practical applications, but few offer workshops in pedagogical implementation. A suggestion would be to implement real-time polling with a colleague and take turns conducting peer-reviews of each classroom. Another advantage of implementing real-time polling with a colleague is that instructors can practice together and brainstorm technical and pedagogical issues to develop solutions.

Based on this study, the researchers have some suggestions for instructors who wish to incorporate real-time polling into their classroom. The first consideration is to ensure that most students have a cell-phone or device to participate in the real-time polling. The results from this research study showed that $98 \%$ of students had cell phones which allowed them to participate. Of those students who had cell phones, $100 \%$ of them indicated that they would prefer using their cell phone for the real-time polling instead of purchasing a "clicker device." Since the majority of students had devices which allowed them to participate, instructors were quite pleased when they were able to quickly query the class and get a response from most students. While there were two students who indicated that they did not have a cell phone and could not participate, the researchers felt that they obtained a much larger number of students participating than they would have normally during class discussions without the use of real-time polling.

Instructors may also face technical challenges when implementing Poll Everywhere. The Poll Everywhere technology requires that students use their own texting service to respond to real-time poll questions. Therefore, students' phones need to have robust enough phone service to be able to text responses. Since the real-time polling required students to text their responses, this was sometimes a usability issue for those students who were unfamiliar with how to use their texting tool on their cell-phone. Additionally, students who used feature phones (non-smart phones) to text their answers were at a disadvantage because it took longer for them to text their response and doing so was a substantially more cumbersome process.

Another challenge for instructors to be aware of is that for Poll Everywhere real-time polling, students are charged for each text that is sent to respond to a question. The costs incurred for texting would normally be far less than the $\$ 40$ for the cost of a clicker device, even though the cost for required clicker devices may be covered by tuition assistance, where data plan costs normally would not. Several of the students provided open-ended comments that indicated they did not have issues with texting by saying, "I think everyone has unlimited texting."

Instructors should also be aware that the time of day may have an impact on students' ability to participate using their own cell phone. For example, during evening classes students'

Journal of Teaching and Learning with Technology, Vol. 4, No. 1, June 2015. jotlt.indiana.edu 
cell phone batteries may begin to lose power and students may want to spare cell-phone use to ensure power for their ride back home.

The classroom environment should be considered by instructors before implementing real-time polling that requires students to use their own cell-phones. Evening classes or lack of phone access may require instructors to use traditional "clicker devices." However, if the environment supports students' use of their own cell phone device, it can save students money as well as the additional burden of having to bring an additional "clicker device."

\section{Significance of the Study}

The ultimate goal for higher education needs to be transfer of learning so that students can take the knowledge learned and utilize it when employed and the instructor is not there to help them. Instead of teaching students to successfully complete midterms, instructors need to design their classes to prepare students to independently use the knowledge in an unpredictable real world situation (Halpern \& Hakel, 2003). Real-time polling can be used to help implement design characteristics that increase students' levels of engagement and participation that will enhance learning transfer. Companies like Poll Everywhere now have real-time polling solutions where students no longer need to purchase "clicker devices", but can use their existing cellphone to respond to real-time polls. Allowing students to use their own device to participate in the real-time polling not only saves them money, but eliminates the need of having to bring an additional device to class since most students usually have them readily available.

\section{Study Limitations}

This study relied on the perceptions of students who responded to a survey. The study also relied on three different instructors implementing real-time polling in their class, so some variation on instructors' levels of expertise in conducting the polls was expected, which might have affected the results. This study asked for students' perceptions if the use of real-time polling increased their understanding of the course content and did not measure assessment results. Another limitation is that the researchers were also the instructors of these courses and this duplicity of roles may have affected their objectivity in analyzing the student responses.

\section{Suggestions and Recommendations for Further Research}

Almost all the students in this study had devices to use for real-time polling with $98 \%$ of students owning cell phones. This allowed students to participate in real-time polling without the necessity of spending extra money for a "clicker" device. A suggestion for further research would be to compare students' perceptions of engagement and participation in classes where students are required to purchase "clicker" devices to classes where students use their own cell phone.

The data for this study was gathered from a survey given to students. A recommendation for further research would be to conduct interviews with students to elicit anecdotal information to gather deeper understandings of how students perceived the use of real-time polling had an impact on their level of understanding course material, their level of participation, and their level of engagement. This study was conducted in one department at one university. Another suggestion for research could be to conduct the study with different academic departments and/or

Journal of Teaching and Learning with Technology, Vol. 4, No. 1, June 2015. jotlt.indiana.edu 
different universities to see if there is a difference with the results, especially if the instructor is not also conducting the study.

Final recommendation for future studies would be to expand the use of real-time polling to teaching students how to utilize the technology. Ninety three percent of students indicated on the survey they felt that using real time polling could benefit their professional life and ninetytwo percent indicated that it would be a marketable skill that could be help differentiate them. In the classes used for this study, the instructor conducted the real-time polling and the students who responded to the polling questions. A recommendation for further research would be to have the students facilitate real-time polling in their presentations to see if their perception of the value of using real-time polling increases.

\section{Conclusion}

The purpose of higher education to ensure learning transfer is so that our students can take the information learned while enrolled in classes and be able to recall and implement this learning when employed at a later date in situations that are different than the classroom. "Teaching for retention during a single academic term to prepare students for an assessment that will be given to them in the same context in which the learning occurs is very different from teaching for long-term retention and transfer" (Halpern \& Hakel, 2003, p. 38). Instructors can use real-time polling to design classes that enhance students' learning transfer. The use of realtime polling will allow students to "practice at retrieval" (Mayer et al., 2008) by providing instructors with frequent opportunities in which they can encourage their students to apply learning while responding to polling questions. Furthermore, real-time polling enables students to develop their metacognition (Halpern \& Hakel, 2003) because they are able to check their own understanding by comparing their own responses to the correct answers. The incorporation of real-time polling will facilitate instructor adoption of more learner-centered strategies that allow students to assume more responsibility of their learning, and also ensure that students are in active learning environments instead of being passive recipients of knowledge (Doyle, 2011).

The instructors involved in this study redesigned their courses using real-time polling to enhance their students' learning transfer. The results of the survey showed that students reported perceived higher levels of participation and engagement. Students' responses also demonstrated that they concluded that the use of real-time polling overwhelmingly helped them to better understand the content.

Based on the statistically significant positive relationship between the variable of Engagement and Participation and the other variable of perceived student learning $(r=.55, p<.01$, $\mathrm{n}=91$ ), it can be concluded that use of real-time polling does engage students. This engagement has been shown to have a positive impact on perceived student learning.

Journal of Teaching and Learning with Technology, Vol. 4, No. 1, June 2015. jotlt.indiana.edu 
Stover, S., Noel, D., McNutt, M., \& Heilmann, S. G.

\section{References}

Abrahamson, A. L. (1999, May). Teaching with Classroom Communication System -- What it involves and why it works. Paper presented at International Workshop, New Trends in Physics Teaching, Puebla, Mexico. Retrieved from Better Education Inc. web site: http://www.bedu.com/Publications/PueblaFinal2.html.

Addison, S., Wright, A., \& Milner, R. (2009). Using clickers to improve student engagement and performance in an introductory Biochemistry class. Biochemistry and Molecular Biology Education, 37(2), 84-91. doi: 10.1002/bmb.20264

Bjork, D. R. (1994). Memory and metamemory: Considerations in the training of human beings. In J. Metcalfe \& A. Shimamura (Eds.). Metacognition: Knowing about knowing, 185-205. Cambridge, MA: MIT Press.

Bligh, D. A. (2000). What's the use of lectures? San Francisco: Jossey-Bass.

Bomia, L., Beluzo, L., Demeester, D., Elander, K., Johnson, M., \& Sheldon, B. (1997). The impact of teaching strategies on intrinsic motivation. Retrieved from ERIC database. (ED418925).

Bransford, J. D., Brown, A. L., \& Cocking, R. R. (2000). How people learn: Brain, mind, experience, and school. Washington, DC: National Academy Press.

Bransford, J. D., Franks, J. J.., Vye, N. J., \& Sherwood, R. D. (1989). New approaches to instruction: Because wisdom can't be told. In S. Vosniadou \& A. Ortony (Eds.), Similarity and analogical reasoning (pp. 470-497). New York, NY: Cambridge University Press.

Bunce, D. M., Flens, E A., \& Neiles, K. Y. (2010). How long can students pay attention in class? A study of student attention decline using clickers. Journal of Chemical Education, 87(12), 1438-1443.

Campt, D., \& Freeman, M. (2010). The meetings revolution will be clickerized. Corporate Meetings \& Incentives, 29(4), 34-35.

Carey, B. (2014). How we learn: The surprising truth about when, where, and why it happens. New York, NY: Random House.

Chabris, C. \& Simons, D. (2009). The invisible gorilla: How our intuitions deceive us. New York, NY: Broadway Paperbacks.

Crosby, A. (1981). A critical look: The philosophical foundations of experiential education. Journal of Experiential Education. 4(1), 9-15. doi: 10.1177/105382598100400103

Dahlstrom, E. (2012). ECAR study of undergraduate students and information technology. Louisville, CO: EDUCAUSE Center for Applied Research. Retrieved from

Journal of Teaching and Learning with Technology, Vol. 4, No. 1, June 2015. jotlt.indiana.edu 
Stover, S., Noel, D., McNutt, M., \& Heilmann, S. G.

http://www.educause.edu/ecar

deWinstanley, A. \& Bork, R. A. (2002). Successful lecturing: Presenting information in ways that engage effective processing. In D. F. Halpern \& M. D. Hakel (Eds.), Applying the science of learning to university teaching and beyond (19-32). New York, NY: Wiley Periodicals.

Doyle, T. (2011). Learner-centered teaching: Putting the research on learning into practice. Sterling, VA: Stylus.

Exeter, D. J., Ameratunga, S., Ratima, M., Morton, S., Dickson, M., Hsu, D., \& Jackson, R. (2010). Student engagement in very large classes: The teachers' perspective. Studies in Higher Education, 35(7), 761-775.

George, D. \& Mallery, P. (2011). SPSS for windows step by step: A simple guide and reference (Eleventh Edition). Boston, MA: Allyn \& Bacon.

Halpern, D. F., \& Hakel, M. D. (2003). Applying the science of learning to the university and beyond. Change, 35(4), 36-41. doi: 10.1080/00091380309604109

Kelly, K. (2011). San Francisco State University Student response systems (“Clickers”): Clicker standardization investigation project report. Retrieved from

http://angieportacio2.myefolio.com/Uploads/CSI_00_Clickers_ProjectReport_v1c.doc

Kim, J., \& Mueller, C.W. (1978). Factor analysis: Statistical methods and practical issues. Newbury Park, CA: SAGE Publications.

Kirsh, D. (2005). Metacognition, distributed cognition and visual design. In P. Gardenfors \& P. Johansson (Eds.), Cognition, education, and communication technology (pp. 147-180). Mahwah, NJ: Lawrence Erlbaum Associate, Inc.

Krathwohl, D. R. (2002). A revision of Bloom's taxonomy: An overview. Theory Into Practice, 41(4), 212-218. doi:10.1207/s15430421tip4104_2.

Lambert, C. (2012). Twilight of the lecture. Harvard magazine. Retrieved from http://harvardmagazine.com/2012/03/twilight-of-the-lecture

Larsen, D. P., Butler, A. C., \& Roediger, H. L. (2013). Comparative effects of test-enhanced learning and self-explanation on long-term retention. Medical Education, 47(7), 674-682. doi: 10.1111/medu.12141

Leimbach, M., \& Maringka, J. (2009). Learning transfer model: A research-driven approach to enhancing learning effectiveness. Wilson Learning. Retrieved from http://www.wilsonlearning.com/images/uploads/pdfs/Learning_Transfer_Approach.pdf

Manke-Brady, M. (2012). Clickers and metacognition: How do electronic response devices (clickers) influence student metacognition? (Doctoral dissertation). Retrieved from USB Digital

Journal of Teaching and Learning with Technology, Vol. 4, No. 1, June 2015. jotlt.indiana.edu 
Stover, S., Noel, D., McNutt, M., \& Heilmann, S. G.

Library http://digitallibrary.usc.edu/cdm/ref/collection/p15799coll3/id/35109

Mayer, R. E., Stull, A., DeLeeuw, K., Almeroth, K., Bimber, B., Chun, D., Zhang, H. (2009). Clickers in college classrooms: Fostering learning with questioning methods in large lecture classes. Contemporary Educational Psychology, 34 (2009), 51-57. doi: 10.1016/j.cedpsych.2008.04.002

Mazur, E. (1997). Peer instruction: A user's manual. Upper Saddle River, NJ: Prentice Hall.

McCabe, M. (2006). Live assessments by questioning in an interactive classroom. In Banks, D. A. (2006) (ed). Audience response systems in higher education: Applications and cases. Hershey, PA: Information Science Publishing.

McKeachie, W. J., Pintrich, P., Lin Y., \& Smith, D. (1986). Teaching and learning in the college classroom: A review of the research literature. Ann Arbor: University of Michigan, NCRIPTAL.

Medina, J. (2008). Brain rules. Seattle, WA: Pear Press.

Miller, K., Lasry, N., Lukoff, B., Schell, J., \& Mazur, E. (2014). Conceptual question response times in Peer Instruction classrooms. Physical Review Special Topics- Physics Education Research, 10(2), 020113-1-020113-6. DOI: 10.1103/PhysRevSTPER.10.020113

Milton, O., Pollio, H. R., \& Eison, J. A. (1986). Cooperative earning for higher education faculty. Phoenix, AZ: American Council on Education and The Oryx Press.

Norris, M. \& Lecavalier, L. (2010). Evaluating the use of exploratory factor analysis in developmental disability psychological research. Journal of Autism and Developmental Disorders, 40(1), 8-20. doi: 10.1007/s10803-009-0816-2.

Organisation for Economic Cooperation and Development (OECD). (2009). Creating effective teaching and learning environments: First results from TALIS. Paris, France: OECD. Retrieved from http://www.oecd.org/education/school/creatingeffectiveteachingandlearningenvironmentsfi rstresultsfromtalis.htm\#Video

Pascarella, E. T., \& Terenzini, P. T. (2005). How college affects students, Volume 2: A third decade of research. San Francisco,CA: Jossey-Bass.

Pashler, H., Rohrer, D., Cepeda, N. J., \& Carpenter, S. K. (2007). Enhancing learning and retarding forgetting: Choices and consequences. Psychonomic Bulletin and Review, 14(2), 187193.

Patry, M. (2009). Clickers in large classes: From student perceptions towards an understanding of best practices. International Journal for the Scholarship of Teaching and Learning, 3(2). Retrieved from http://academics.georgiasouthern.edu/ijsotl/v3n2.html

Journal of Teaching and Learning with Technology, Vol. 4, No. 1, June 2015. jotlt.indiana.edu 
Stover, S., Noel, D., McNutt, M., \& Heilmann, S. G.

Penner, J. G. (1984). Why many college teachers cannot lecture: How to avoid communication breakdown in the classroom. Springfield, IL: Charles C. Thomas.

Poll Everywhere. (n.d.). Frequently asked questions. Retrieved from http://www.polleverywhere.com/faq

Powell, S., Straub, C., Rodriguez, J., \& VanHorn, B. (2011). Using clickers in large college psychology classes: Academic achievement and perceptions. Journal of the Scholarship of Teaching and Learning, 11(4), 1-11.

Ratey, J. (2002). A user's guide to the brain: Perception, attention, and the four theaters of the brain. New York, NY: Vintage Books.

Renkl, A., Atkinson, R. K., Maier, U. H., \& Staley, R. (2002). From example study to problem solving: Smooth transitions help learning. Journal of Experimental Education, 70 (4), 293-315.

Roediger, H. L. \& Karpicke, J. D. (2006). Test-enhanced learning: Taking memory tests improves long-term retention. Psychological Science, 17(3), 249-55.

Rogers, C. R. (1983). As a teacher, can I be myself? In Freedom to Learn for the '80's. Columbus, OH: Charles E. Merrill Publishing Company.

Schwartz, D. L., \& Bransford, J. D. (1998). A time for telling. Cognition and Instruction, 16(4), 475-522. doi: 10.1207/s1532690xci1604_4

Seitz, A. R., Kim, R., \& Shams, L. (2006). Sound facilitates visual learning. Current Biology, 16(4), 1422- 1427.

Wiggins, G., \& McTighe, J. (2005). Understanding by design. Alexandria, VA: ASCD.

Wiggins, G. (2012). Transfer as the point of Education. [Web log comment]. Retrieved from http://grantwiggins.wordpress.com/2012/01/11/transfer-as-the-point-of-education/

Willis, J. (2006). Researched-based strategies to ignite student learning. Alexandria, VA: ASCD.

Zadina, J. (2008). Six weeks to a brain-compatible classroom. Publisher: Author.

Journal of Teaching and Learning with Technology, Vol. 4, No. 1, June 2015. jotlt.indiana.edu 